\title{
Covid-19: identifying and isolating asymptomatic people helped eliminate virus in Italian village
}

\author{
Michael Day
}

London, UK

An Italian academic has claimed striking evidence that most people infected with covid-19 show no symptoms but are still able to infect others, which he says has huge implications for testing policy, particularly in hospitals.

Sergio Romagnani, a professor of clinical immunology at the University of Florence, has reported how blanket testing in a completely isolated village of roughly 3000 people in northern Italy saw the number of people with covid-19 symptoms fall by over $90 \%$ within 10 days.

Vo'Euganeo, $50 \mathrm{~km}$ west of Venice, was closed off by authorities in mid-February, at which point repeat RNA testing of the entire population began. All those with positive tests were quarantined. The number of people sick from covid-19 fell from 88 to seven in less than 10 days, Romagnani reported.

In an open letter to the authorities in the Tuscany region, Romagnani wrote that the great majority of people infected with covid-19-50-75\% — were asymptomatic, but represented "a formidable source" of contagion.

"The percentage of people infected, even if asymptomatic, in the population is very high and represents the majority of cases, particularly, but not only, among young people. Isolation of asymptomatics is essential for controlling the spread of the virus and the seriousness of the epidemic," he said.

He concluded that employing large scale testing to find and isolate asymptomatic cases, particularly among health workers who might unwittingly pass the virus to colleagues or patients, was a vital strategy in containing the spread of the disease.

He told La Repubblica, "We're deciding not to test doctors and nurses if they're not developing symptoms. But in the light of the results, this decision could be dangerous; hospitals risk becoming zones with high infections rates in which infected people are not isolated."

Tom Jefferson, a doctor and epidemiologist at the Nordic Cochrane Centre based in the Veneto region, said the
Vo'Eugeano study results would have major implications for testing policy, if they were representative of covid-19 elsewhere. He noted that Romagnani's findings appeared to contradict a WHO report based on covid-19 in China. ${ }^{2}$ This suggested that "the proportion of truly asymptomatic infections is unclear but appears to be relatively rare and does not appear to be a major driver of transmission."

Other reports suggested that testing on the Diamond Princess cruise ship did find a significant number of symptomless cases. Jefferson told The BMJ, "There are clearly some contradictions here." Nonetheless, he said it should be mandatory to do blanket testing.

Jonathan Ball, professor of molecular virology at the University of Nottingham, said that the "prevalence of asymptomatic or mild disease and its role in virus transmission and the potential role of children in driving this pandemic" are among the "key matters that need to be resolved."

With 3405 deaths from covid-19, Italy's fatalities now exceed those of China. There were 427 deaths in the 24 hours until 6 pm on 19 March, according to Italy's civil protection chief Angelo Borrelli. China's death toll is 3245 .

Two doctors died from the covid-19 in Como on 19 March, according to the federation of Italian doctors' guilds. They were respiratory specialist Giuseppe Lanati and family doctor Luigi Frusciante, both of whom had come out of retirement to work during the emergency. There have now been 13 deaths among Italian doctors, the federation said.

1 Dobbiamo cambiare rotta, tampone a chi non ha sintomi. Corriere della Sera. Mar 2020. https://corrierefiorentino.corriere.it/firenze/notizie/cronaca/20 marzo 15/dobbiamocambiare-rotta-ef23a500-669a-11ea-a40a-86d505f82a96.shtml.

2 WHO. Report of the WHO-China joint mission on coronavirus disease 2019 (COVID-19). www.who.int/docs/default-source/coronaviruse/who-china-joint-mission-on-covid-19-finalreport.pdf.

Published by the BMJ Publishing Group Limited. For permission to use (where not already granted under a licence) please go to http://group.bmj.com/group/rights-licensing/ permissions 